\title{
A STUDY ON THE IMPACT OF EMPLOYEE SATISFACTION ON QUALITY AND PROFITABILITY OF ORGANIZATIONS
}

\author{
D Swaroopa ${ }^{1}$ and Prof.B.Sudhir ${ }^{2}$
}

Abstract- Human Resource Management is getting more important in the business nowadays, because people and their knowledge are the most important aspects affecting the productivity of the company. One of the main aspects of Human Resource Management is the measurement of employee satisfaction. Companies have to make sure that employee satisfaction is high among the workers, which is a precondition for increasing productivity, responsiveness, quality, and customer service. Satisfaction is a measure of how happy employees are with their job and working environment. It is a key factor when measuring the organizational success.

The purpose of this study is to observe the relationship between employee satisfaction and organizational success to attain profits. In this research paper various variables responsible for employee satisfaction has been discussed such as Organization development factors, Job security factors, Work task factors, Policies of compensation and benefit factor and opportunities which give satisfaction to employees such as Promotion and career development leadership, job satisfaction, motivation, rewards and cultural differences also has been described This paper also deals the various ways by which one can improve employee satisfaction. The data was collected through self administrated questionnaire which contains multiple choice questions and open-ended questions. In conclusion, it seems reasonable to believe that understanding of employee role is extremely important as it appears key factor in the success of modern organization.

Keywords - Employee satisfaction, Human Resource Management, compensation, Organization development, Career development

\section{INTRODUCTION}

Employee satisfaction is the favorableness or un-favorableness with which the employee views his work. It expresses the amount of agreement between one's expectation of the job and the rewards that the job provides. Employee satisfaction is looked at in areas such as management, understanding of mission and vision, empowerment, teamwork, communication and coworker interaction. Employee satisfaction is essential for employee retention. Organizations need to retain deserving and talented employees for long term growth and success.

\section{LITERATURE REVIEW}

Schneider et al. (2003) report analyses of employee attitude survey data aggregated to the organizational level of analysis. These author explored the relationships between several facets of employee satisfaction and organizational financial (return on assets; ROA) and market performance (earnings per share; EPS) using data from 35 organizations over a period of eight years. Thus, in contrast to previous studies, Schneider and his colleagues' study was able to make some inferences about directional causality (i.e., are employee attitudes a stronger cause of organizational performance than the reverse). Their results showed consistent and statistically significant positive relationships (over varied time lags) between attitudes concerning satisfaction with security, satisfaction with pay, and overall job satisfaction with financial (ROA) and market performance (EPS). Although these findings are

\footnotetext{
${ }^{1}$ Department of Management studies Geethanjali Institue of Science and Technology, SPSR Nellore, Andra pradesh, india

${ }^{2}$ Department of Business Management S.V. University, Tirupathi, Andra pradesh, india
} 
consistent with applied researchers' and managers' implicit beliefs, their study was not without some surprises. One of the more surprising findings was related to overall job satisfaction and the performance criteria.

Hanges, Smith, and Salvaggio (2003) recently observed, researchers' micro-orientation towards the job attitudeperformance relationship is somewhat perplexing, given that the interest in employee attitudes had much of its impetus in the 1960s when organizational scientists such as Argyris (1964), Likert (1961), and McGregor (1960) suggested that the way employees experience their work would be reflected in organizational performance. Historically, the job satisfaction-performance linkage has been primarily discussed by theorists from the Sociotechnical and Human Relations schools of thought.

According to the Sociotechnical approach (e.g., Emery \& Trist, 1960), organizational performance depends on congruence between the technical and social structures of the organization. Building on this notion, the Human Relations perspective posits that satisfied workers are productive workers (e.g., Likert, 1961; McGregor, 1960). Thus, organizational productivity and efficiency is achieved through employee satisfaction and attention to employees' physical as well as socioemotional needs. Human relations researchers further argue that employee satisfaction sentiments are best achieved through maintaining a positive social organizational environment, such as by providing autonomy, participation, and mutual trust (Likert, 1961).

In a unique study conducted by Harter et al. (2002), the authors conducted a meta analysis of studies previously conducted by The Gallup Organization. The study examined aggregated employee job satisfaction sentiments and employee engagement, with the latter variable referring to individual's involvement with as well as enthusiasm for work. Based on 7,939 business units in 36 organizations, the researchers found positive and substantive correlations between employee satisfaction-engagement and the business unit outcomes of productivity, profit, employee turnover, employee accidents, and customer satisfaction. More importantly, these researchers explored the practical utility of the observed relationships.

\section{MAJOR FORCES Working Conditions}

Because employees spend so much time in their work environment each week, it's important for companies to try to optimize working conditions. Such things as providing spacious work areas rather than cramped ones, adequate lighting and comfortable work stations contribute to favorable work conditions.

\section{Opportunity for Advancement}

Employees are more satisfied with their current job if they see a path available to move up the ranks in the company and be given more responsibility and along with it higher compensation. Many companies encourage employees to acquire more advanced skills that will lead to the chance of promotion. Companies often pay the cost of tuition for employees taking university courses, for example. During an employee's annual performance review, a supervisor should map out a path showing her what she needs to accomplish and what new skills she needs to develop in order to be on a track to advancement within the organization.

\section{Workload and Stress Level}

Dealing with a workload that is far too heavy and deadlines that are impossible to reach can cause job satisfaction to erode for even the most dedicated employee. Falling short of deadlines results in conflict between employees and supervisors and raises the stress level of the workplace. Many times, this environment is caused by ineffective management and poor planning. The office operates in a crisis mode because supervisors don't allow enough time for employees to perform their assigned tasks effectively or because staff levels are inadequate.

\section{Respect from Co-Workers}

Employees seek to be treated with respect by those they work with. A hostile work environment -- with rude or unpleasant coworkers -- is one that usually has lower job satisfaction. In an August 2011 survey published by FoxBusiness.com, 50 percent of those responding said they had personally experienced a great amount of workplace incivility. Fifty percent also believe morale is poor where they work. Managers need to step in and mediate conflicts before they escalate into more serious problems requiring disciplinary action. Employees may need to be reminded what behaviors are considered inappropriate when interacting with coworkers. 


\section{Relationship with Supervisors}

Effective managers know their employees need recognition and praise for their efforts and accomplishments. Employees also need to know their supervisor's door is always open for them to discuss any concerns they have that are affecting their ability to do their jobs effectively and impeding their satisfaction at the office.

\section{Financial Rewards}

Job satisfaction is impacted by an employee's views about the fairness of the company wage scale as well as the current compensation she may be receiving. Companies need to have a mechanism in place to evaluate employee performance and provide salary increases to top performers. Opportunities to earn special incentives, such as bonuses, extra paid time off or vacations, also bring excitement and higher job satisfaction to the workplace.

\section{OBJECTIVES OF THE STUDY}

- To study the job satisfaction levels of employees on various job dimensions.

- To study the relationship between the demographical factors of the employee with satisfaction level.

- To measure the satisfaction level of employees on various factors and provide suggestions for improving satisfaction.

- To analyze the current satisfaction level of the employees in the company.

\section{LIMITATIONS OF STUDY}

- Time is the major constraint.

- Analysis is based on the responses given by the employees.

- There could be chances for bias from the employees' side to give the socially accepted answer.

- Data bias is very difficult to control and to overcome.

- In designing questionnaire, there could be chances for not including all the factors that affect the employee satisfaction.

\section{RESEARCH METHODOLOGY}

Research methodology is a way to systematically solve the research problem. It deals with the objective of a research study, the method of defining the research problem, the type of hypothesis formulated, the type of data collected, method used for data collecting and analyzing the data etc.The analysis follows descriptive research method. Descriptive studies aims at portraying accurately the characteristics of a particular group or situation. Descriptive research is concerned with describing the characteristics of a particular individual or a group.

\section{Sample Data:}

Sampling technique used in this study is 'Random sampling'. The sample size taken for this study is 116 . In order to gather the data for understanding the level of employee satisfaction level, a sample of 116 respondents were asked to take part in a self-administered questionnaire. The population for the existing research is employees working in public and private sectors of Nellore City. The present study utilizes a non probability sampling technique that is convenience sampling. Convenience sampling is a sampling technique that obtains and collects the relevant information from the sample or the unit of the study that are conveniently available.

Procedure: The questionnaire was distributed among 120 respondents in Nellore City of Andra Pradesh. These respondents are selected based on the criteria above mentioned. Before giving the questionnaire, the purpose of the study and questions were explained to the respondents so they can easily fill the questionnaire with relevant responses. A total of 116 questionnaires collected. After collecting, the completed questionnaires were coded and analyzed to get results.

\section{VII.TOOLS FOR ANALYSIS}


The two survey instruments used to analyse collected data.

1. Percentage Analysis

2. Chi-square Analysis

\section{PERCENTAGE METHOD:}

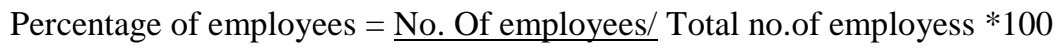

CHI SQUARE ANALYSIS :A chi-square test, also referred to as a test is any statistical hypothesis test wherein the sampling distribution of the test statistic is a chi-square distribution when the null hypothesis is true. Chi-squared tests are often constructed from a sum of squared errors, or through the sample variance. Test statistics that follow a chi-squared distribution arise from an assumption of independent normally distributed data, which is valid in many cases due to the central limit theorem. A chi-squared test can be used to attempt rejection of the null hypothesis that the data are independent.

$\mathrm{H}_{0}$ (Null Hypothesis) $=$ There is no significant difference between actual value and expected value.

$\mathrm{H}_{1}$ (Alternative Hypothesis) $=$ There is significant difference between actual value and expected value.

$\chi^{2}=($ Actual Value - Expected Value $) 2 /$ Expected Value

$$
\chi^{2}=(\mathbf{0}-\mathbf{e})_{2} / \mathbf{e}
$$

$\chi^{2}(\mathrm{cal})>\chi^{2}(\mathrm{tab})$, then $\mathrm{H}_{0}$ is rejected.

$\chi^{2}(\mathrm{cal})<\chi^{2}(\mathrm{tab})$, then $\mathrm{H}_{0}$ is accepted.

\section{RESULTS AND ANALYSIS}

Profile of the Respondents:

Personal and demographic information of the respondents is presented in the following table

\section{SAMPLE DISCRIPTION:}

\begin{tabular}{|c|c|c|c|}
\hline Variable & category & frequency & $\begin{array}{c}\text { percentage } \\
(\%)\end{array}$ \\
\hline Gender & Male & 33 & 28 \\
& Female & 83 & 72 \\
\hline Marital status & Single & 44 & 38 \\
& Married & 72 & 62 \\
\hline Age & $20-30$ years & 32 & 27 \\
& 30-40 years & 68 & 59 \\
& Above 40 years & 16 & 14 \\
\hline Education & Inter & 12 & 10 \\
& Bachelor Degree & 78 & 67 \\
& Master degree & 26 & 23 \\
\hline
\end{tabular}

Hypothesis Testing: This segment of the research finally tests the model after satisfying the requirements of reliability and Validity. The Causal relationships of the independent variables were on the dependent variables

$>$ Recruitment procedure and Employee Satisfaction According to the results of the research, the variable of recruitment process has a significant positive relationship with Employee Satisfaction. It means the most of the employees nearly $83 \%$ of employees satisfied about recruitment process of organizations.

$>$ Training and Development and Employee Satisfaction The results of the research confirm the significant positive relationship between Training and Development and Employee Satisfaction with. According to these results, Training and Development programmes contributes to learn different skills nearly $88 \%$ of Employee Satisfied. 
Drievance Handling and Employee Satisfaction: According to the results of the analysis the variable of Grievance Handling has a significant positive relationship with Employee Satisfaction. It means the most of the employees nearly $75 \%$ of employees satisfied about Grievance Handling procedure of organizations.

> Equal Employement Opportunities and Employee Satisfaction: The result of the research nearly 59\% of employees says organization is treating employees equally while $32 \%$ of employees says according to designations giving importance and $9 \%$ of employees says not fair treatment to all employees.

$>$ Level of stress and Employee Satisfaction: According to the results of the research States that $50 \%$ of employees says organization is creating stress while $50 \%$ of employees says organization is not creating stress to reach the targets within the time. The calculated value of $\chi^{2}$ doesn't support null hypothesis. According to responses given by employees and by applying statistical application of chi square we came to know women are undergoing more stress than men.

$>$ Working Hours and Employee Satisfaction: The results of the research confirm the significant positive relationship between working hours and Employee Satisfaction. According to these results $53 \%$ of employees are satisfied with the working hours while $47 \%$ of employees are not satisfied with the working hours provided by the organizations.

$>$ Salary benefit and Employee Satisfaction: According to the results of the analysis $6 \%$ employees says highly satisfied, $47 \%$ employees says satisfied, $20 \%$ employees says neutral while $16 \%$ employees are dissatisfied and $12 \%$ employees are highly dissatisfied with their salaries and benefits.

$>$ Welfare programmes and Employee Satisfaction: The results of the research confirm the significant positive relationship between Welfare programmes and Employee Satisfaction. According to these results $70 \%$ of employees are satisfied with the welfare facilities provided by the organizations.

> Pay and Promotion and Employee Satisfaction The regression results of the research confirm the significant positive relationship between Pay and promotion and Employee Satisfaction with. According to these results, Pay and promotion contributes more than $60 \%$ to Employee dissatisfied about promotions and hikes provided by the organization.

$>$ Personal life influence and Employee Satisfaction: According to the results of the research, the variable of personal life of employees has a significant positive relationship with Employee Satisfaction. It means the most of the employees 58\% of employees said they are not getting enough time to spend with the family, nearly $42 \%$ of employees said they are getting enough time to spend with the family.

> Motivational factors and Employee Satisfaction: The result of the analysis 37\% of employees are motivated by incentives, $20 \%$ of employees are motivated by promotion, $17 \%$ of employees are motivated by recognitions and $26 \%$ of employees are motivated by motivation talks.

> Job Safety and Security and Employee satisfaction Regression analysis of the Employee Satisfaction model depicts that there is a positive relationship between Job safety and security and Employee satisfaction with $(B e t a=.092)$ and $(p<.048)$. The results suggest that Job Safety and Security contributes almost 9\% t to Employee Satisfaction. The result of the study support H3.

$>$ Working Condition and Job Performance Regression results of the research confirm the significant positive relationship between Working Condition and Job Performance with (Beta=.101) and $(\mathrm{p}<.023)$. According to these results, Working Condition contributes 10\% more to Job performance.

\section{IV.CONCLUSION}

Based on the survey, conclude that employees are satisfied but the organizations need to improve some of the facilities so that employee would become highly satisfied and the productivity and performance levels also increase. To this purpose the factors chosen for this study good working conditions, Recruitment process, Training and Development, Grievance Handling, Pay and Promotion, Equal Employment Opportunities, level of stress, work timings, welfare programmes. The organizations need to provide good working conditions for the ease of employees to be able to work in an efficient and effective manner. The organizations must provide effective pay and benefits,good welfare programmes, implementation of suitable grievance redressal procedures, recruitment process, equal employment opportunities, safety measures and incentives, ,promotions, recognition, involvement of employees in decision making process and provide all other motivational factors to increase overall satisfaction level of the employees.

\section{REFERENCES}

[1] Armstrong, M. (2006). A Handbook of Human resource Management Practice, Tenth Edition, Kogan Page Publishing, London, , p. 264 
[2] Aziri, B. (2008). Menaxhimi i burimeve njerëzore, Satisfaksioni nga puna dhe motivimi i punëtorëve, Tringa Design, Gostivar, , p. 46 Christen, M., Iyer, G. and Soberman, D. (2006). Job Satisfaction, Job Performance, and Effort: A Reexamination Using Agency Theory, Journal of Marketing, Januaryr, Vol. 70, pp. 137-150 Davis, K. and Nestrom, J.W. (1985). Human Behavior at work: Organizational Behavior, 7 edition,McGraw Hill, New York, p.109 Herzberg, H. F. (1976). Motivation-Hygiene Profiles, p. 20

[3] George, J.M. and Jones, G.R. (2008). Understanding and Managing Organizational behavior, Fifth Edition, Pearson/Prentice Hall, New Yersey, p. 78

[4] Hoppock, R. (1935). Job Satisfaction, Harper and Brothers, New York, p. 47 Kaliski, B.S. (2007). Encyclopedia of Business and Finance, Second edition, Thompson Gale, Detroit, p. 446 Lawler, E.E. III and Porter, L.W. (1967).

[5] The Effect of Performance on Job Satisfaction, Industrial Relations, pp. 20-28 Locke, E.A. and Latham, G.P. (1990).

[6] A theory of goal setting and task performance, Prentice Hall, p.4 Luthans, F. (1998). Organizational Behavior, 8 Edition, McGraw-Hill/Irwin, Boston, p. 147 Mullins, J.L. (2005).

[7] Management and organizational behavior, Seventh Edition, Pearson Education Limited, Essex, p. 700 Rue, L.W. and Byars, L. (2003). Management, Skills and Application, 10 ed., McGraw-Hill/Irwin, New York, p. 259 Aziri

[8] Bhatti, K., \& Qureshi, T. (2007). Impact of employee participation on job satisfaction, employee commitment and employee productivity. International Review of Business Research Papers, 3(2), $54-68$.

[9] Bowen, D. E., \& Ostroff, C. (2004). Understanding HRM-firm performance linkages: The role of "strength" of the HR system. Academy of Management Review, 29, 203-221

[10] Carpitella, Bill. (2003). Make residential construction the industry of choice [Electronic version]. Professional Builder, Oct 2003.

[11] Cranny, C.J., Smith, P.C., \& Stone, E.F. (1992). Job satisfaction: How people feel about their jobs and how it affects their performance. New York: Lexington.

[12] Derek R. Allen, Merris Wilburn, (2002) -Linking customer and employee satisfaction to the bottom line, ASQ quality press publications cat log, Milaukee, WI.

[13] Employee satisfaction and opinion surveys. (n.d.). Retrieved February 25, 2011, fromhttp://www.infoquestcrm.co.uk/employee_surveys.html

[14] Freeman, Shelly, (2005). Employee satisfaction: The key to a successful company.Retrieved on March 15, 2011http://library.lp.findlaw.com/articles/file/00301/008927/title/Subject/topic/Employment.

[15] Harter, J. K., Schmidt, F. L., \& Hayes, T. L. (2002). Business-unit level relationship between employee satisfaction, employee engagement, and business outcomes: A meta-analysis. Journal of Applied Psychology, 87, 268-279.

[16] Heskett, J. L., T. O. Jones, G. W. Loveman, W. E. Jr. Sasser, L. A. Schlesinger. 1994. Putting the service-profit chain to work. Harvard Business Review 72 (2)

[17] Hunter, W., \& Tietyen, D. (1997). Business to business marketing: Creating a community of customers. LincolnwoodIllinois, McGraw-Hill Professional.

[18] Judge, T.A., Hulin, C.L. (1993), "Job satisfaction as a reflection of a disposition: amultiple source causal analysis", Organizational Behavior and Human Decisions Processes, Vol. 56, pp. 388-421.

[19] Likert, R. L. (1961). The human organization. New York: McGraw-Hill.

[20] Maloney, W.F., \& McFillen, J.M. (1986). Motivational implications of constructionwork. Journal of Construction Engineering and Management, March 1986, 137-151.

[21] [McGregor, D. (1960). The human side of enterprise. New York: McGraw-Hill.

[22] Miller, J. L. (2006). Coach Yourself to Succeed @ Work: How to Achieve Optimal Performance and Job Satisfaction.CA, Dorrance Publishing Co.

[23] Moyes, G. D., \& Shao, L. P., Newsome, M. (2008). Comparative analysis of employee job satisfaction in the accounting profession. Journal of Business \& Economics Research, 6(2), 65-81 